treatment before the law in accordance with the International Covenant on Civil and Political Rights.

The government held its nose when 13,000 Poles used the opportunity of the self-exiled class provisions (before that class was ellminated) to enter Canada as refugees when Poland was no longer, and had not been for some time, a refugee producing country. We allowed them to "abuse" the principle of the system if not

\section{Now is the time to reverse ourselves before we dig ourselves in deeper.}

the law. We cannot claim purity in either our motives, procedures or conduct to justify standing on the high horse of principle and, at the same time, perpetuating unnecessary suffering. And the costs of upholding principles which are already seriously compromised are enormous. If we add to these factors the very high cost for each case actually deported, the very high numbers that will enter the illegal underground in Canada and the very doubtful projection that the process can ever be completed by the end of 1991, it is very difficult to continue supporting the present system. However, if an amnesty is offered now, there is a further complication. Some will have been deported while if you got into the stream much later, you will have earned an amnesty. It just would not be fair.

But only 167 have been deported to the end of October and about 200 cases will only have been deported by the end of 1990. Now is the time to reverse ourselves before we dig ourselves in deeper. I now urge the Tory government and Barbara to change the stubborn defence of the present method of dealing with the backlog. $\mathbf{B}$

(Howard Adelman is a Professor of Philosophy at York University and directs the Centre for Refugee Studies, a research centre focused on refugees which was recently recognized by the Government of Canada as a Centre of Excellence.)

\title{
IF YOU LOVE, THEN HAVE COMPASSION...
}

\author{
Fr. Olivier Morin SJ, \\ Jesuit Refugee Service, Toronto
}

For four and a half years I have been serving Vietnamese refugees in the camp in Southeast Asia: a year on Pulau Bidong, in Malaysia, and three and a half years at Phanat Nikhom in Thailand. During this period, the situation has changed in the camps, principally because of the decision taken that Vietnamese who have arrived after 14th March, 1989, will not be recognized as "refugees", but will only be known as "asylum seekers".

Whatever my own opinion about the moral and humanitarian value of such a decision, I am forced to accept it as a fact and to assess the consequences. Nothing can allow us to think seriously that this decision will be reconsidered. On the contrary new events, such as the significant migration from East Europe, for example, can but reinforce it.

From this decision several consequences have followed:

1. A very small number of asylum seekers (between $10 \%$ and $16 \%$ ), who have documentation proving they have suffered persecution or that their lives were threatened, have been recognized by the ad hoc commission (they are 'screened in') and can seek to be accepted in a third country. Minors who have their father or mother in a third country may be screened in, but a sponsorship by a brother, uncle or friend helps no one.

2. The great majority do not possess such documents or cannot substantiate their claims and soare rejected ('screened out').

a) From the moment of arrival in the camp, some know very well that they have no chance, and rather than wait long months in difficult conditions they prefer to accept the evidence and request 'voluntary repatriation'. But they must present themselves to a Vietnamese government delegation, and this is an obstacle that diminishes their desire to return to Vietnam. What are the guarantees? Even the UNHCR is vague on this point.

b) Some, hoping against all hope, want to try their luck and wait their turn to be screened. This is a very slowprocess. The recent arrivals will wait one or even two years if nothing is done to speed up the pace. They can also appeal against an unfavourable decision, but the results are negligible. After all this they will still be in a hopeless situation and caught in the severity of camp life.

c) Finally, there is a group who do not actually request voluntary repatriation, but who have not formally opposed a return, so the first asylum country decides to send them back. This group is not normally required to go before the Vietnamese delegation. They may feel unlucky, but they do not lose face. They are something like those who missed the boat before it left the beach.

Having lived at Phanat Nikhom and followed this matter quite closely my personal convictions are as follows:

- Nothing, absolutely nothing can persuade me that the date limit of 14 March, 1989, will be lifted. So our responsibility is considerable, and what possible considerations are there that can allow us to say: "maintain your refusal". We are playing with human lives if we insist on such a position. It would be wrong for us to propose our wishes (which are easy to voice from the freedom of our new countries), if they conflict with the reality.

- In such a situation we have no right to encourage false hopes. The truth, however painful it may be, must be spoken, otherwise we are responsible for the (possible) desperate actions that asylum seekers take when they have been misled even by those who wish to help them.

- The approach mentioned in (c), above, may offer one possible way forward, particularly if we can offer some solidarity to those sent back. It avoids the humiliation of having to publicly admit to failure. Another problem is that in order to leave, the Vietnamese have sold everything, thus their return is made even more difficult 
by the fact of their responsibilities for their families. Why not organize a program for financial help? If these returnees could count on say, even $\$ 50$ or $\$ 100$ a month, for one or two years, in order to help them start up again in Vietnam, then they would not be going back completely empty-handed. A sponsorship program of this type will help themavoid the distress of the camps

... the situation has
changed in the camps,
principally because of the
decision taken that
Vietnamese who have
arrived after 14th March,
1989, will not be
recognized as "refugees"

where their future is blocked and also avoid the bitterness of being deceived by everyone.

I have just come from the camps, I know what I am saying, I have been living there, not for just a week but for three and a half years at Phanat Nikhom. The situation is even worse in Hong Kong. I know that many Vietnamese people, both in the camps and in the resettlement countries, insist that by adamantly refusing, the asylum seekers will finally win out. But the discussions that I have had with the UNHCR and also with the third country delegations convince me that this is false.

I have worked very hard in the resettlement countries to find sponsorships. My Vietnamese friends can witness that whenever the slightest opportunity was offered, I have grabbed it . I understand very well all that the notion of return implies, by way of suffering and renunciation. But how will it be when this return takes place after an even longer wait and after so many promises have been rendered empty?

At this moment when I leave Asia in order to work with refugees in Africa, I wish to speak what is true for the refugees in Asia, so that you too will have the courage to recognize your responsibility. To offer illusions to them can be fatal. $\mathbf{R}$

\section{CONFERENCE OF THE CANADIAN ASSOCIATION OF AFRICAN STUDIES}

\author{
YORK UNIVERSITY \\ MAY 16 - 18, 1991
}

\section{THE MAIN THEME - AFRICA IN THE 1990s: DEVELOPMENT WITH DEMOCRACY}

There will be a stream of consecutive sessions on refugee related issues. The suggested topics include:

- Root Causes : Human Rights in Africa

- Conflicts between Asylum and Majoritarian Democracy

- Development Assistance Related to National and Refugee Self Determination

- Neo-Colonialism: International Agencies and NGOs working with Refugees

- Repatriation of Refugees and its effects on Democracy.

Please send your enquiries to:

Mr. Ogenga Otunnu or Prof. Howard Adelman

Centre for Refugee Studies, York University

4700 Keele St., North York, Ontario

Canada M3J 1P3

Tel: (416) 736-5663 • Fax: (416) 736-5837

\section{SIETAR INTERNATIONAL XVII ANNUAL CONGRESS}

\section{ANNUAL INTERNATIONAL CONGRESS MAY 1 - 16, 1991 IN BANFF SPRINGS, ALBERTA, CANADA}

The main theme -

"Creating Global Synergy: The Intercultural Perspective"

will be examined in relation to four major areas:

Global Communication: Languages, Human and Electronic;

Globalization, Visions and Realities;

Global Creativity and Synergy; and Global Ethics.

For more information and registration materials, please contact:

$$
\begin{gathered}
\text { SIETAR International Secretariat } \\
733 \text { 15th St., NW, Suite } 900 \\
\text { Washington, DC 20005, U.S.A. } \\
\text { Tel.: (202) 737-5000 }
\end{gathered}
$$

Fax: (202) 737-5553 